\title{
PROFIL ATLET PENCAK SILAT PRA PORDA DILIHAT DARI ASPEK PSIKOLOGI DAN FISIOLOGI
}

\author{
Mia Rosalina \\ Universitas 17 Agustus 1945 Cirebon \\ email: k.meeya.janoko@gmail.com
}

\begin{abstract}
Abstrak
Tujuan penelitian ini adalah untuk mengetahui: (1) derajat pendidikan, sosial, dan ekonomi profil atlet pencak silat (2) Fisiologis atlet pencak silat berdasarkan aspek fisik, (3) Motivasi atlet pencak silat ke tim SPOU Cirebon Pra-PORDA Di Kabupaten Bogor. Cara mengembangkan prestasi atlet ke tim SPOU Cirebon Pra-PORDA di Kabupaten Bogor. Metode deskriptif digunakan pada penelitian ini dengan angket, survey, wawancara, dan tes sebagai instrumen pengumpulan data. Hasil penelitian ini adalah sebagai berikut: (1) Pendidikan latar belakang orang tua mereka adalah sebagian besar lulusan sekolah dasar (2) Latar belakang ekonomi orang tua mereka adalah mayoritas miskin (3) Latar belakang sosial orang tua mereka adalah buruh dan tidak bekerja (4) Kualitas fisik rata-rata (5) Motivasi berprestasi tinggi.
\end{abstract}

Kata Kunci: Pencak Silat, Fisiologi, Psikologi

\begin{abstract}
The study purpose is to reveal : (1) The profile education, social, and economic degree of parent's pencak silat atheletes (2) Physiological of atheletes based on physical aspect, (3) Motivation on pencak silat atheletes to team SPOU Cirebon Pra-PORDA in Kabupaten Bogor. How to develop athelets achievement to team SPOU Cirebon Pra-PORDA in Kabupaten Bogor. Descriptive methode is used on this study with quistionnaire, survey, interview, and test as instrument to collect of data. the result of this study as follow: (1) Educational of background of their parent is a large part of elementary school graduate (2) Economic background of their parent is poor majority (3) Social background of their parent is laborer and does not work (4) Quality of physical is average (5) Achievement motivation is high.
\end{abstract}

Keywords: Pencak Silat, Physiology, and Psychology

(C) 2017 STKIP Muhammadiyah Kuningan 


\section{PENDAHULUAN}

Olahraga pencak silat merupakan olahraga asli dari Indonesia.Tidak ada yang tahu kapan, dimana, dan bagaimana pertama kali proses perkembangan olahraga pencak silat tersebut berlangsung, hal itu disebabkan informasi yang tersedia masih sangat terbatas. Namun demikian menurut catatan sejarah, pencak silat berkembang di kawasan Indonesia seperti di ungkapkan oleh Dreager, Maryono dalam (Mulyana, 2013, hlm, 79) pentjak-silat is certainly to be termed a combative from indigenous to Indonesia. But it is a synthesis product, not purely autogenic endeavor.

Semakin cepat perkembangan zaman, perkembangan pencak silat pun semakin berkembang. Berdasarkan buku (peraturan pencak silat, 2007, hlm, 1) dalam ranah prestasi kategori pertandingan pencak silat terdiri dari : 1. Kategori Tanding 2. Kategori Tunggal 3. Kategori Ganda 4. Kategori Regu Kategori tunggal adalah: kategori pertandingan pencak silat yang menampilkan seorang pesilat memperagakan kemahirannya dalam jurus tunggal baku secara benar, tepat dan mantap, penuh penjiwaan, dengan tangan kosong dan bersenjata (golok dan toya), serta tunduk kepada ketentuan dan peraturan yang berlaku. Jurus tunggal terdiri dari 7 jurus tangan kosong, 4 jurus senjata golok, 3 jurus senjata toya dan total kesemua jurusnya adalah 14 jurus dengan total 100 gerakan.
Hal ini diperkuat dalam situs (tsuad.blogspot.com/2012/jurus-tunggal-ipsitsuad.html) "Pada kongres persilat tahun 1998, jurus tunggal baku ditetapkan menjadi salah satu kategori yang dipertandingkan. Jurus ini disusun oleh tim yang anggotanya terdiri dari pakar pencak silat dari empat negara pendiri persilat, yaitu: a. IPSI (Ikatan Pencak Silat Indonesia) b. PERSISI (Persekutuan Silat Singapura) c. PESAKA (Persekutuan Silat Kebangsaan Malaysia) d. PERSIB (Persekutuan Silat Kebangsaan Brunei Darussalam)."

Olahraga pencak silat ini memerlukan kemampuan fisik dan keterampilan gerak yang sangat prima.Hal ini berkaitan dengan kondisi internal berupa struktur anatomis, fungsi fisiologis, dan sistem persyarafan. Ketiga faktor tersebut memiliki dampak yang sangat berarti dalam hal penguasaan suatu keterampilan. Lutan (1998: 13) menjelaskan bahwa"faktorfaktor yang mempengaruhi pencapaian prestasi digolongkan menjadi dua kategori, yaitu faktor endogen dan faktor ekstrogen. Faktor endorgen yaitu struktur anatomis, fisiologis, sistem syaraf dan struktur kepribadian." Faktor lain yang sangat menunjang dalam pencapaian prestasi pencak silat adalah faktor psikososial.

Dalam proses interaksi, pencak silat memiliki kemungkinan yang berpengaruh terhadap pencapaian prestasi, baik pengaruh positif maupun negatif. Pengaruh positif 
timbul apabila adanya kesesuaian penafsiran gerakan dan perilaku yang satu dengan yang lainnya(kompak), sedangkan pengaruh negatif akan muncul apabila ada penafsiran gerakan dan perilaku yang berbeda. Perilaku seorang atlet akan ditentukan oleh latar belakang tersebut mulai dari latar belakang keluarga, ekonomi, pengalaman selama proses interaksi, dan lingkungan tempat mereka tinggal atau bekerja. Ketiga faktor ini akan berpengaruh terhadap aspek psikologi dalam proses interaksi dengan individu/atlet lainnya.

Berdasarkan hasil pengamatan di lapangan, prestasi atlet olahraga pencak silat Kota Cirebon pada event-event yang diikuti, bahwa ditinjau dari aspek anatomis atlet pencak silat Kota Cirebon umumnya memiliki kelemahan yang signifikan. Hal ini bisa dilihat dari struktur antropometrik yaitu berat badan yang overweight, tinggi badan yang tidak proporsional, ditinjau secara fisiologis kemampuan daya tahan cardio-respitori, daya tahan otot, kekuatan, kecepatan, power, kelentukan, dan kelincahan cenderung relatif kurang baik. Data lain menunjukkan secara psikologis atlet pencak silat Kota Cirebon mempunyai perasaan tidak percaya diri, kurang motivasi, tertutup, pendiam, cepat marah dan mudah tersinggung.

Agar prestasi olahraga pencak silat di Kota Cirebon mencapai prestasi yang menggembirakan pada berbagai event, perlu kiranya pendekatan dan penelitian yang mengkaji aspek fisiologis dan psikologis atlet pencak silat sebelum mereka mengikuti suatu event. Isu sentral dalam penelitian ini adalah secara fisiologis dan psikologis atlet pencak silat di Kota Cirebon harus memiliki persyaratan dan kecakapan yang bagus, agar dapat mengoptimalkan kemampuannya dalam setiap event yang diikutinnya sehingga menghasilkan suatu pencapaian prestasi yang diharapkan.

Berdasarkan hal diatas, maka penelitian ini terfokus pada faktor fisiologis dan psikologis atlet pencak silat Tim SPOU Pencak Silat Kota Cirebon dalam PraPORDA Tahun 2016 di Kabupaten Bogor. Rumusan masalah dalam penelitian ini yaitu pada faktor fisiologis dan psikologis atlet pencak silat Tim SPOU Pencak Silat di Kota Cirebon, secara rinci masalah yang diteliti yaitu:

1. Bagaimana profil keluarga atlet pencak silat Tim SPOU Kota Cirebon berdasarkan faktor ekonomi, sosial dan pendidikan?

2. Bagaimana profil fisiologis atlet pencak silat Tim SPOU Kota Cirebon ditinjau dari aspek fisik?

3. Bagaimana profil psikologis atlet pencak silat Tim SPOU Kota Cirebon ditinjau dari motif yang mendorongnya menjadi atlet, kehidupan sosial, sikap dan hobinya? 
4. Bagaimana upaya pembinaan atlet pencak silat Tim SPOU Kota Cirebon agar berprestasi pada PORDA di Kabupaten Bogor?

Tujuan yang ingin dicapai dari penelitian ini adalah :

1. Memperoleh gambaran latar belakang keluarga atlet pencak silat Tim SPOU Kota Cirebon dilihat dari aspek ekonomi, sosial dan pendidikan.

2. Memperoleh gambaran dimensi fisiologis atlet pencak silat Tim SPOU Kota Cirebon seperti antropometri, kecepatan, daya tahan, kelincahan, fleksibilitas, dan power.

3. Memperoleh data langsung mengenai faktor psikologis atlet pencak silat seperti motivasi yang melatarbelakanginya menjadi atlet, hobi, sikap, cara berinteraksi dengan sesama dan lingkungan.

Memperoleh gambaran tentang cara membina dan meningkatkan prestasi yang cocok dan memadai sehingga berdampak positif pada pencapaian prestasi atlet SPOU Kota Cirebon Pra-PORDA di Kabupaten Bogor.

\section{METODE}

Penelitian ini menggunakan penelitian deskriptif dengan bersumber pada data empirik di lapangan dan berbagai kajian teori sebagai dasar kerangka berpikirnya. Nasir dalam Sutresna (2006) bahwa "Penelitian deskriptif dilakukan untuk membuat deskripsi secara sistematis faktual dan akurat mengenai fakta, sifat beserta hubungan antara fenomena yang diselidiki."

Responden dalam penelitian ini adalah seluruh atlet putra dan putri Tim SPOU Pencak Silat Kota Cirebon PraPORDA di Kabupaten Bogor.

Teknik pengumpulan data dalam penelitian ini adalah dengan cara analisis suvey dan tes fisik, untuk pengambilan data dan informasi mengenai profil psikologis atlet pencak silat dilakukan dengan cara penyebaran angket yang memuat hal-hal yang akan diteliti dan di wawancara. Sedangkan informasi yang ingin digali dari profil fisiologis melalui serangkaian tes dan pengukuran fisik atlet antara lain tes kecepatan, daya tahan, kelincahan, fleksibilitas, dan power sedangkan pengukurannya melalui pengukuran antropometri.

\section{HASIL PENELITIAN}

1. Profil keluarga atlet pencak silat Kota Cirebon Pra-PORDA di Kabupaten Bogor berdasarakan faktor ekonomi, sosial dan pendidikan.

Berdasarkan hasil pengumpulan dan pengolahan data, maka diperoleh gambaran mengenai latar belakang keluarga atlet pencak silat Kota Cirebon Pra-PORDA di Kabupaten Bogor sebagai berikut : pada umumnya orang tua atlet yang mengikuti cabang olahraga pencak silat berasal dari keluarga yang mempunyai budaya olahraga pencak silat (turun temurun). 
Kecenderungan olahraga pencak silat ini digeluti dan digemari oleh keluarga yang berasal dari keluarga menengah kebawah.
Disamping itu latar belakang pendidikan keluarga atlet pencak silat rata-rata lulusan SMA.

Tabel 1 : Hasil Distribusi Latar Belakang Atlet Pencak Silat SPOU Kota Cirebon PraPORDA Kabupaten Bogor

\begin{tabular}{|c|c|c|c|c|}
\hline No & $\begin{array}{c}\text { Latar Belakang } \\
\text { Keluarga }\end{array}$ & Putra & Putri & Ket \\
\hline \multirow{4}{*}{1.} & \multirow{4}{*}{ Pendidikan } & $5 \% \mathrm{SD}$ & $5 \% \mathrm{SD}$ & \\
\hline & & $15 \%$ SMP & $35 \%$ SMP & \\
\hline & & $70 \%$ SMA & $50 \%$ SMA & \\
\hline & & $10 \%$ PTT & $10 \%$ PTT & \\
\hline \multirow{3}{*}{2.} & \multirow{3}{*}{ Ekonomi } & $80 \%$ Kurang mampu & $70 \%$ Kurang mampu & \\
\hline & & $20 \%$ Menegah & $20 \%$ Menegah & \\
\hline & & & $10 \% \mathrm{Mampu}$ & \\
\hline \multirow{2}{*}{3.} & \multirow{2}{*}{$\begin{array}{c}\text { Mata } \\
\text { Pencaharian }\end{array}$} & $70 \%$ Buruh & $70 \%$ Wiraswasta & \\
\hline & & $30 \%$ Tidak Bekerja & $30 \%$ Tidak Bekerja & \\
\hline
\end{tabular}

Gambaran dimensi fisiologis atlet pencak silat seperti antropometri, kecepatan, daya tahan, kelincahan, fleksibiltas, dan power

Tabel 2 : Hasil Pengukuran Antropometri dan Pengetesan Kondisi Fisik

\begin{tabular}{|c|c|c|c|c|}
\hline No & Fisiologi Atlet & Putra & Putri & Ket \\
\hline \multirow{4}{*}{1.} & Antropometri tubuh & & & \\
\hline & * rata-rata tinggi badan & sedang & sedang & \\
\hline & * rata-rata berat badan & sedang & sedang & \\
\hline & * panjang tungkai & sedang & kurang & \\
\hline \multirow{5}{*}{2.} & Kondisi Fisik & & & \\
\hline & * daya tahan tubuh & cukup & cukup & \\
\hline & * power & baik & cukup & \\
\hline & * fleksibilitas & cukup & baik & \\
\hline & * kecepatan & baik & cukup & \\
\hline
\end{tabular}

2. Faktor Psikologis atlet SPOU Kota Cirebon Pra-PORDA Kabupaten ditinjau dari motif yang mendorongnya menjadi atlet, kehidupan sosial, sikap dan hobinya: 
Berdasarkan hasil penyebaran angket dan wawancara yang peneliti lakukan, maka diperoleh hasil sebagai berikut : atlet putri memilih cabang olahraga pencak silat di latarbelakangi karena minimnya masyarakat yang mengetahui dan menyukai pencak silat, sehingga menumbuhkan minat yang besar bagi atlet putri menggeluti olahraga ini persentasenya $65 \%$. Sedangkan atlet putra sebanyak $75 \%$. Hal lain yang melatarbelakangi mereka memilih olahraga pencak silat karena mereka memilikipotensiyang ditunjang oleh lingkungan tempat tinggal, sekolah dari SD, SMP dan SMA maupun tempat kerja, dengan persentasenya atlet putra $80 \%$, atlet putri sebanyak $60 \%$. Selanjutnya $80 \%$ atlet putra yang memilih pencak silat dengan alasan materi dan $65 \%$ atlet putri. $100 \%$ atlet putra dan putri memilih pencak silat adalah karena alasan pekerjaan. Atlet putra dan putri $90 \%$ bertujuan untuk meraih prestasi yang tinggi,sedangkan sisanya untuk prestise dan bonus. Motivasi tertinggi diberikan oleh orang tua sebesar $80 \%$ kepada atlet putra dan putri, dorongan dari teman/pacar/suami/istri sebesar $60 \%$.

3. Memperoleh gambaran tentang cara membina dan meningkatkan prestasi yang sesuai dan memadai sehingga berdampak positif pada pencapaian prestasi di PORDA Kabupaten Bogor.
Berdasarkan hasil wawancara dan observasi yang penulis lakukan, maka dalam meningkatkan prestasi atlet pencak silat SPOU Kota Cirebon pada PORDA Kabupaten Bogor Tahun 2017 antara lain:

1. Pembentukan managemen pengelolaan PORDA yang kondusif dan komprehensif yang dibentuk dalam satuan tugas, sehingga atlet bisa merasa nyaman dan tenang sebelum, selama dan setelah bertanding.

2. Pemeliharaan sumber daya pelatih, dokter, psikolog yang berkualitas dan mampu memahami berbagai karakteristik atlet.

3. Adanya program latihan yang terstruktur baik dengan ditunjang sarana prasarana serta sistem monitoring.

Meningkatkan sistem reward dan punishment pada semua elemen yang tergabung dalam Tim PORDA pencak silat.

\section{SIMPULAN}

Berdasarkan uraian diatas, kesimpulan dalam penelitian ini adalah :

1. Orang tua atlet pencak silat putra dan putri ditinjau dari sudut ekonomi khususnya mata pencahariannya mayoritas berlatarbelakang sebagai buruh, dari segi pendidikan mereka mayoritas berasal dari lulusan SMA, sedangkan ditinjau dari latarbelakang ekonomi berasal dari keluarga kurang mampu, kecenderungan memiliki minat dan bakat terhadap pencak silat sangat besar pada orang tua atlet. 
2. Ditinjau dari sudut antropometri tubuh khususnya pada atlet putra dan putri berada pada ukuran tinggi dan berat badan yang sedang. Sedangkan untuk keadaan kondisi fisik tubuh atlet pencak silat berada pada level cukup.

3. Pada umumnya atlet pencak silat Tim SPOU Kota Cirebon Pra-PORDA Kabupaten Bogor mempunyai motif yang sangat besar yaitu keinginan untuk mendapatkan prestasi tinggi, yang nantinya berdampak pada terbukannya peluang untuk mendapatkan pekerjaan di instansi/lembaga pemerintahan/swasta. Hal ini berdampak pada peningkatan rasa percaya diri atlet pada saat berlatih dan selama pertandingan. Penelitian ini terungkap dari raihan prestasi yang tinggi pada seleksi PraPORDA Kabupaten Bogor Tahun 2016 di Kota Cirebon yaitu dengan lolosnya Tim putra dan putri Kota Cirebon ke PORDA Tahun 2017.

Berdasarkan uraiandiatas, maka rekomendasi penelitian ini adalah pembinaan atlet olahraga pencak silat untuk Pra-PORDA di Kabupaten Bogor Tahun 2017 sebaiknya menitikberatkan pada aspek fisik atlet. Hal ini dikarenakan kondisi fisik atlet berada pada level cukup. Disamping itu, perlu diperhatikan selanjutnya adalah pemilihan pelatih atlet yang berkualitas dan berdedikasi tinggi sehingga menjadi motivator bagi para atlet.

\section{DAFTAR PUSTAKA}

Bompa T. Theory and methodology of trainning. Iowa : Kendal and Hunt publishing company 1990.

Cooper, Kenneth H. 1997. Aerobic (terjemahan). Jakarta : PT. Gramedia

Harsono. 1988. Coaching Dan Aspekaspek psikologis Dalam Coaching. Jakarta : CV. Tambak Kusuma

Lutan, R. (1998). Olahraga (kajian teori dan aplikasi). Seri bahan ajar FPOK UPI Bandung.

Sucipto. (2009). Pembelajaran Pencak Silat. FPOK UPI Bandung.

Thomas, Jerry R, and Nelson, Jack K. (1985). Introduction to Research in Health, Physical Education, Recreation and Dance. Champaign, Illinois: Human Kinetics Publisher, Inc 